\title{
Perception of the learning environment among the students in a nursing college in Eastern Nepal
}

\author{
Erina Shrestha ${ }^{1 *}$, Ram Sharan Mehta ${ }^{1}$, Gayanand Mandal', Kriti Chaudhary ${ }^{2}$ and Nirmala Pradhan ${ }^{3}$
}

\begin{abstract}
Background: Learning environment is an important base for learning processes of students and for preferences of future workplaces. It is considered as an essential factor in determining the success of an effective curriculum and the students' academic achievements. This study attempts to assess the perception of learning environment among the nursing students.
\end{abstract}

Methods: A descriptive cross-sectional study design was used to conduct the study among 122 nursing students studying at B.P. Koirala Institute of Health Science. Data were collected following total enumerative sampling method using a self-administered questionnaire. Dundee Ready Educational Environment Measure (DREEM) inventory tool was used to assess the perception of learning environment. Descriptive statistics (frequency, percentage, mean and standard deviation) was used to describe the demographic and other related variables. One way Analysis of Variance (ANOVA) was used to find out the difference in the overall scale score and its subscales across the selected socio-demographic variables (age, ethnicity, residence, year of enrollment) of the respondents.

Results: The mean age of the students was $21 \pm 1.46$ years. Majority of the students were from Province no. 1 (57.4\%) and largely from Sunsari district (25.4\%). First year students were found to be more satisfied (68.23\%) with the educational environment (136.45 \pm 16.93$)$ compared to student of other years. Academic self-perception $(21.94 \pm 3.42)$ was the highest scoring subscale (68.57\%) while the social self-perception (16.43 \pm 2.96$)$ was the lowest (58.66\%). The overall DREEM score (131.25 \pm 15.82 out of 200) indicated that perception of learning environment among the students was positive. Despite overall positive perception, students perceived that the teachers were authoritative and there is lack of good support system for the students at the time of stress. The total DREEM score varied significantly between the years of enrollment $(p<0.05)$.

Conclusion: The current study showed positive perception of learning environment which varied significantly according to the year of enrollment. However improvements are required across all the five domains for the high quality educational environment. Future qualitative studies are recommended to confirm and to have in-depth understanding of this finding.

Keywords: Perception, Learning environment, Students, Nursing

\footnotetext{
* Correspondence: erinaashrestha@gmail.com

${ }^{1}$ Department of Medical Surgical Nursing, B.P. Koirala Institute of Health

Sciences, Dharan, Nepal

Full list of author information is available at the end of the article
}

(c) The Author(s). 2019 Open Access This article is distributed under the terms of the Creative Commons Attribution 4.0 International License (http://creativecommons.org/licenses/by/4.0/), which permits unrestricted use, distribution, and reproduction in any medium, provided you give appropriate credit to the original author(s) and the source, provide a link to the Creative Commons license, and indicate if changes were made. The Creative Commons Public Domain Dedication waiver (http://creativecommons.org/publicdomain/zero/1.0/) applies to the data made available in this article, unless otherwise stated. 


\section{Background}

Educational environment is one of the most important factor in determining the success of an effective curriculum and subsequently the students' academic success [1]. The quality of educational climate impacts the quality of the curriculum, teaching and learning consideration and developing student outcomes as practitioners [2]. Bloom described the educational or learning environment concept as "the conditions, external stimuli and forces which may be physical, social, as well as intellectual forces which challenge on the individual and influence students' learning outcomes" [3].

A good or effective learning environment is not limited to only teacher's good communication skills, knowledge, credibility and preparedness contributing towards teaching excellence. An environment that best prepares the students for their future professional life and contributes towards their personal and psychosomatic development as well as the social well-being is considered as an ideal academic environment [1].

As cited by Sayed and El-Sayed [4], Jiffry et al. indicated that the major domains encompassed in an educational environment of any health school are self-perception of learning, self-perception of teachers, academic selfperception, self-perception of atmosphere, and social self-perception.

Roff and McAleer have indicated that environment that is competitive, authoritarian, stressful, or threatening may de-motivate students and weaken their interest and commitment for learning process. Environment that is collaborative, collegial, and supportive may enhance greater engagement of nursing students and this may lead to improved preparedness for clinical training [4].

Previous study showed that students' perception of their current learning environment is even a stronger predictor of learning outcomes at a university than their prior achievements at school [5]. Mayya \& Roff [6] had found significant differences in the students' perceptions of learning environment between academic achievers and under- achievers.

It is evident from recent literatures that the educational environment encountered by students has a significant impact on their behavior, satisfaction with the course of study, perceived well- being, aspirations and academic achievement $[7,8]$.

Studying the learning environment is important in improving the quality of an educational program [3]. The most used and accessible way of examining the educational environment is to evaluate the students' perception of that environment [9].

Systematic review conducted by Miles et al. [8] showed that perception of the learning environment using Dundee Ready Educational Environment Measure (DREEM) has been conducted in at least 20 countries around the world. However these studies are predominantly conducted among the medical undergraduate students. Study in this regard in developing countries such as Nepal is limited, especially among nursing students.

Many methods have been tried to obtain such a reading and these include questionnaire tools, focus group studies, student feedback etc. Among them, the DREEM questionnaire is said to be one of the widely used and more specific tools in relation to assessing educational environment, especially in relation to medical education. DREEM has been validated as a universal diagnostic inventory for assessing the quality of educational environment $[4,5,8]$.

Apart from this, the findings from the DREEM have been found to be consistent with qualitative information attained via interviews [10]. Secondly even though the DREEM have been used mainly for medical students, it was constructed by a panel of faculty from not only the medicals schools but also the other health professions and items were constructed based on their perceptions of learning climates conducive to education in the health profession, not just medicine [8].

\section{Methods}

The main objective of the study was to assess the perception of learning environment among the nursing students and to find out the difference in the overall score of perception of learning environment and its subscales across the selected variables.

\section{Study design and setting}

A descriptive cross-sectional design was employed for this study. The study was carried out among the B.Sc. Nursing students studying at B.P. Koirala Institute of Health Science (BPKIHS), tertiary level medical university in eastern Nepal.

\section{Participants}

Required sample for this study was estimated using the formula, $n=\mathrm{z}^{2} \boldsymbol{\sigma}^{2} / \mathrm{d}^{2}$. Considering the study conducted by Kohli and Dhaliwal [11], where, Mean $=101.13$, Standard deviation, SD $(\boldsymbol{\sigma})=21.14$, Absolute precision (d) $=4.04$ (4\% of mean) $Z_{5 \%}=1.96$ and adding $10 \%$ for nonresponse, the final sample size was 115 . The total students currently enrolled in the program were 128; hence all the students were enrolled in the study following the total enumerative sampling method. Students who were currently enrolled in the B.Sc. Nursing program present at the time of data collection and who gave consent were included in the study.

\section{Instrument}

Data were collected using a self-administered questionnaire based on the objectives of the research which consisted of two sections: 
Section A: socio-demographic characteristics of the students (age, ethnicity, residence and year of enrollment). Section B: items related to perception of learning environment based on Dundee Ready Education Environment Measure (DREEM).

DREEM is an internationally validated, non-culturally specific inventory. It includes 50 items with five point Likert scale $(0-4)$. These items are categorized in five sub scales as Student's Perception of Learning (12 items), Student's Perception of Teachers (11 items), Student's Academic Self Perception (8 items), Student's Perception of Atmosphere (12 items), Student's Social Self Perception (7 items). There are nine negative items (items 4, 8, 9, 17, $25,35,39,48$, and 50 ), for which correction is made by reversing the scores; thus after correction, higher scores indicate disagreement with that item. Each individual item with a mean score of $\geq 3.5$ are true positive points; those with a mean of $\leq 2$ are problem areas; scores in between these two limits indicate aspects of the environment that could be enhanced. The maximum global score for the questionnaire is 200 which is interpreted as follows: 0$50=$ very poor, $51-100=$ many problems, $101-150=$ more positive than negative, $151-200=$ excellent $[8,11-14]$. The alpha coefficient of the tool for this study was 0.86 which indicates adequate reliability for measurement.

The research instrument was pretested to identify any ambiguities in the questionnaire. It was performed by taking $10 \%$ of the sample size i.e. 12 meeting the inclusion criteria in a different nursing college and those samples were not included in the main study.

\section{Ethical consideration}

Ethical clearance was obtained from the Institutional Review Committee (IRC) BPKIHS and approval letter was provided by the research Committee, BPKIHS. Permission from the concerned authority was obtained to conduct the study. Permission was obtained for the use of DREEM inventory. Written informed consent was obtained from respondents prior to the data collection.

\section{Data collection}

English version of the DREEM questionnaire was used. The questionnaire was distributed to students of each year separately at the end of the year in a leisure class. Before the questionnaire was distributed the students were briefed about the purpose of the study, data collection procedure and the meaning of some terms such as authoritarian, ridicule, factual learning which were found difficult by the students during pretesting. Researcher was present during the data collection and precautions were taken to ensure that the students didn't copy answer from their friends' questionnaires. Around 30 min was taken by each participant to complete the questionnaire. Total 122 students were present at the time of data collection who completed the questionnaire which were analyzed.

\section{Statistical analysis}

The data were collected, coded, checked for completeness and entered in Microsoft EXCEL 2007 and transformed in SPSS (Statistical Package for Social Sciences) PC 11.5.0 version. Descriptive statistics (frequency, percentage, mean and standard deviation) was used to describe the demographic and other related variables. One way Analysis of Variance (ANOVA) was used to find out the difference in the score of the perception of learning environment and its subscales across the selected socio-demographic variables (age, ethnicity, residence and year of enrollment).

\section{Results}

Around two-third (66.39\%) of the respondents belonged to the age group 20-22 years. The age of the respondents ranged from 18 to 25 years with the mean age of 21 years \pm 1.46 . Around one fourth of the respondents were Brahmin (26.2\%) and Mongolian (25.4\%) each. Out of total students from first to fourth year, only around one fifth (19.7\%) of the respondents were from second year. Students from all over Nepal were currently studying in the B.Sc. nursing program. More than half $(57.4 \%)$ of the respondents were from Province no. 1. Around one fourth (25.4\%) of the respondents were from Sunsari district. Almost half $(47.6 \%)$ of the respondents were from the other 28 districts altogether. As BPKIHS is located in Sunsari district of Province no. 1, the students near to this area may be more interested in studying here.

The overall score for perception of learning environment was $131.25 \pm 15.82$ ( $65.62 \%$ of maximum score). Among the five subscales, Student's Academic selfperception was the highest scoring subscale (68.57\%) with the mean score of $21.94 \pm 3.42$ while the social selfperception was the lowest (58.66\%) with the mean score of $16.43 \pm 2.96$. Subscales means and standard deviation along with percentage are depicted in Table 3.

On individual item analysis, the mean of individual items revealed that ten items scored three or more than three which indicated the positive aspect. However none of the items scored more than 3.5. Scores of six items were below two. The mean scores of the majority of the items were between two and three.

Significant differences were found between the years of enrollment for the overall perception of the learning environment $(p<0.05)$. The score for subscale student's perception of teachers also varied significantly between the years of enrollment $(p<0.05)$. There was no significant difference in the score of the perception of the learning across the other selected variables. The details of the result are depicted in the Tables 1, 2, 3 and 4 . 
Table 1 Socio-demographic Characteristics of the Respondents $(n=122)$

\begin{tabular}{|c|c|c|c|}
\hline Characteristics & Category & Frequency & Percentage (\%) \\
\hline \multirow[t]{3}{*}{ Age (completed years) } & $\leq 19$ & 19 & 15.57 \\
\hline & $20-22$ & 81 & 66.39 \\
\hline & $>22$ & 22 & 18.04 \\
\hline \multicolumn{4}{|c|}{ Mean $\pm S D: 21 \pm 1.46$, Range (18-25) } \\
\hline \multirow[t]{6}{*}{ Ethnicity } & Brahmin & 32 & 26.2 \\
\hline & Chhetri & 18 & 14.8 \\
\hline & Newar & 10 & 8.2 \\
\hline & Mongolian & 31 & 25.4 \\
\hline & Terai origin & 23 & 18.9 \\
\hline & Others & 8 & 6.6 \\
\hline \multirow[t]{4}{*}{ Class } & First Year & 40 & 32.8 \\
\hline & Second Year & 24 & 19.7 \\
\hline & Third Year & 30 & 24.6 \\
\hline & Fourth Year & 28 & 23.0 \\
\hline \multirow[t]{7}{*}{ Residence (Province) } & 1 & 70 & 57.4 \\
\hline & 2 & 23 & 18.9 \\
\hline & 3 & 12 & 9.8 \\
\hline & 4 & 9 & 7.4 \\
\hline & 5 & 4 & 3.3 \\
\hline & 6 & 1 & 0.8 \\
\hline & 7 & 3 & 2.5 \\
\hline \multirow[t]{4}{*}{ Residence (District) } & Sunsari & 31 & 25.4 \\
\hline & Morang & 21 & 17.2 \\
\hline & Jhapa & 12 & 9.8 \\
\hline & Others (28 districts) & 58 & 47.6 \\
\hline
\end{tabular}

\section{Discussion}

The overall DREEM mean score obtained in this study indicated that the student's perception of learning environment was positive. Though this score highlighted the student centered approach followed in the nursing program, improvements are needed to have a positive impact on the student's achievement, satisfaction and success [15]. Study conducted by Roff et al. [12] in Nepalese Health Profession Institution showed similar overall DREEM score of 130. Similar to this study, positive perception of learning environment was seen in several other studies conducted in various Nursing colleges of Malaysia [3], Suadi Arabia [4] and Iran [9]. Similar finding was seen in studies conducted by Arab [16], Imanipour [17], Bakshi [18] and Victor [19] that showed the overall DREEM score of 103.54, 104.39, 114.3 and 119 respectively. A study conducted among medical and nursing undergraduate students of Srilanka also showed positive perception [20]. Similar studies were predominantly conducted in medical schools of India [1, 11],
Pakistan [21], Malaysia [22], Saudi Arabia [23], Iran [24], Egypt [25], Australia [15], Brazil [26], Sweden [14] and the findings from those studies were in agreement with that of the current study.

In contrast to the present finding, a study conducted in Egypt [7] among the nursing students showed poor perception towards their learning environment. Contrast result to the present finding was also seen in study conducted by Al-Ayed [27] in a medical college in Riyadh with the overall DREEM score of 89.9. Studies conducted by Aghamolaei [28] and Taheri [2] in medical schools of Iran also reported potential problems with the total DREEM score of 99.6, 98 respectively. However no studies were found by the researcher in which the perception of the learning environment was excellent. Variation in population and setting studied might be the reason for variation in score.

In the present study, the interpretation of each five subscales of DREEM revealed a perception which was directed more towards the positive side. Similar finding was seen in the study conducted by Said [3], Sayed [4], Mayya [6], Farajpour [9], Bakshi [24] and Sajid [29].

On individual item analysis ten items scored three or more than three which indicated the positive aspect. The students perceived that there are opportunities to develop their interpersonal skills, the teachers are knowledgeable and good at providing feedback, the teaching helped to develop their competence and confidence. The students are confident about passing the exam. They have good friends and are comfortable socially. These all findings revealed the liberal atmosphere present in the institution.

According to Mayya and Roff [6], items scoring more than 3.5 are the excellent areas. However in the present study none of the items scored more than 3.5 which indicated that there were no particularly excellent areas and lot of areas needed improvement. This finding is consistent with the findings of the study conducted by Abussad [30].

Six items scored two or less than two. These low scores are the areas of concern. The student identified that increased tiredness and stress to enjoy the course, lack of good stress support system, factual learning and authoritarian teachers as significant problems. The impression that the teachers are authoritarian and emphasized on factual learning has also been shown by other studies conducted in India [1] and Iran [5]. Perceived lack of good support system is also seen in a study conducted in Iran by Aghamolaei [28] and Imanipour [17]. For a positive academic environment, the overall well-being of the students' needs to be taken into consideration in terms of workload maintaining a balance between the academic activities and the recreation time [1] so that they can enjoy the course. The findings from the present study indicate 
Table 2 Mean scores of individual items of Dundee Ready Educational Environment Measure (DREEM)

SN Domain Items
Students' Perception of Learning
1. I am encouraged to participate in class
2. The teaching is often stimulating
3. The teaching is student centered
4. The teaching helps to develop my competence
5. The teaching is well focused
6. The teaching helps to develop my confidence
7. The teaching time is put to good use
8. The teaching over-emphasizes factual learning ${ }^{\text {a }}$
9. I am clear about the learning objectives of the course
10. The teaching encourages me to be an active learner
11. Long term learning is emphasized over short term
12. The teaching is too teacher-centered ${ }^{\text {a }}$
Students' Perception of Teachers

13. The teachers are knowledgeable

14. The teachers are patient with patients

15. The teachers ridicule the students ${ }^{a}$

16. The teachers are authoritarian ${ }^{\text {a }}$

17. The teachers have good communication skills with patients

18. The teachers are good at providing feedback to students

19. The teachers provide constructive criticism here

20. The teachers give clear examples

21. The teachers get angry in class ${ }^{\text {a }}$

22. The teachers are well prepared for their classes

23. The students irritate the teachers ${ }^{\text {a }}$

Students' Academic Self-perception

24. Learning strategies which worked for me before continue to work for me now

25. I am confident about my passing this year

26. I feel I am being well prepared for my profession

27. Last year's work has been a good preparation for this year's work

28. I am able to memorize all I need

29. I have learned a lot about empathy in my profession

30. My problem solving skills are being well developed here

31. Much of what I have to learn seems relevant to a career in healthcare

Students' Perception of Atmosphere

32. The atmosphere is relaxed during the ward teaching

33. This school is well timetabled

34. Cheating is a problem in this school ${ }^{a}$

35. The atmosphere is relaxed during lectures

Mean SD

3.01

$2.58 \quad 0.78$

$2.60 \quad 0.86$

$3.18 \quad 0.70$

$2.72 \quad 0.79$

3.190 .60

$2.79 \quad 0.79$

$1.49 \quad 0.80$

$2.90 \quad 0.73$

$2.88 \quad 0.75$

$2.70 \quad 0.84$

$2.19 \quad 1.03$

3.21

2.84

241

1.37

2.99

2.02 1.05
Table 2 Mean scores of individual items of Dundee Ready Educational Environment Measure (DREEM) (Continued)

\begin{tabular}{|c|c|c|c|}
\hline SN & Domain Items & Mean & SD \\
\hline 36. & $\begin{array}{l}\text { There are opportunities for me to develop } \\
\text { interpersonal skills }\end{array}$ & 3.30 & 0.64 \\
\hline 37. & I feel comfortable in class socially & 3.02 & 0.60 \\
\hline 38. & The atmosphere is relaxed during seminars/tutorials & 2.92 & 0.75 \\
\hline 39. & I find the experience disappointing ${ }^{a}$ & 2.40 & 1.04 \\
\hline 40. & I am able to concentrate well & 2.48 & 0.86 \\
\hline 41. & The enjoyment outweighs the stress of the course & 2.50 & 0.95 \\
\hline 42. & The atmosphere motivates me as a learner & 2.70 & 0.79 \\
\hline 43. & I feel able to ask the questions I want & 2.78 & 0.91 \\
\hline \multicolumn{4}{|c|}{ Students' Social Self-perception } \\
\hline 44. & $\begin{array}{l}\text { There is a good support system for students who get } \\
\text { stressed }\end{array}$ & 1.69 & 1.17 \\
\hline 45. & I am too tired to enjoy the course ${ }^{a}$ & 1.98 & 1.09 \\
\hline 46. & I am rarely bored on this course & 1.90 & 1.07 \\
\hline 47. & I have good friends in this school & 3.20 & 0.77 \\
\hline 48. & My social life is good & 2.89 & 0.68 \\
\hline 49. & I seldom feel lonely & 2.10 & 1.20 \\
\hline 50. & My accommodation is pleasant & 2.67 & 0.85 \\
\hline
\end{tabular}

${ }^{\mathrm{a}}$ Reverse scoring

that the support system provided by the faculty and the institution should be improved in order to facilitate the learning of the students. As most of the students are not locals and need to stay away from their parents and guardians, the students should be made aware of the available support system such as emphasizing the role of the preceptors who are accessible in the institution to help the students. It also focuses on to improvise the student centered approach which is followed in the nursing program.

Significant difference was found between the perception of learning environment and the year of enrollment. This finding is in accordance to the findings given by

Table 3 Scores of Overall Perception of Learning Environment and its subscales $(n=122)$

\begin{tabular}{llllll}
\hline Characteristics & $\begin{array}{l}\text { No. of } \\
\text { items }\end{array}$ & $\begin{array}{l}\text { Obtainable } \\
\text { score }\end{array}$ & Mean & SD & $\begin{array}{l}\text { Mean } \\
\text { Percent }\end{array}$ \\
\hline $\begin{array}{l}\text { Students' Perception of } \\
\text { Learning }\end{array}$ & 12 & $0-48$ & 32.22 & 4.49 & 67.12 \\
$\begin{array}{l}\text { Students' Perception of } \\
\text { Teachers }\end{array}$ & 11 & $0-44$ & 28.89 & 4.39 & 65.64 \\
$\begin{array}{l}\text { Students' Academic Self- } \\
\text { perception }\end{array}$ & 8 & $0-32$ & 21.94 & 3.42 & 68.57 \\
$\begin{array}{l}\text { Students' Perception of } \\
\text { Atmosphere }\end{array}$ & 12 & $0-48$ & 31.78 & 4.94 & 66.20 \\
$\begin{array}{l}\text { Students' Social Self- } \\
\text { perception }\end{array}$ & 7 & $0-28$ & 16.43 & 2.96 & 58.66 \\
$\begin{array}{l}\text { Total Perception of } \\
\text { Learning Environment }\end{array}$ & 50 & $0-200$ & 131.25 & 15.82 & 65.62 \\
\hline
\end{tabular}


Table 4 Association of Perception of learning environment and its subscales with year of enrollment $(n=122)$

\begin{tabular}{llllll}
\hline Domains & First Year & Second Year & Third Year & Fourth Year & $P$-value \\
\hline Students' Perception of Learning & $33.38 \pm 4.57$ & $32.42 \pm 4.56$ & $32.23 \pm 4.64$ & $30.39 \pm 3.72$ & 0.61 \\
Students' Perception of Teachers & $30.58 \pm 4.99$ & $28.21 \pm 3.52$ & $28.70 \pm 4.30$ & $27.25 \pm 3.52$ & 0.01 \\
Students' Academic Self-perception & $22.35 \pm 3.62$ & $21.33 \pm 3.27$ & $22.43 \pm 3.72$ & $21.36 \pm 2.89$ & 0.43 \\
Students' Perception of Atmosphere & $32.98 \pm 5.55$ & $31.00 \pm 4.72$ & $31.83 \pm 4.67$ & $30.68 \pm 4.28$ & 0.22 \\
Students' Social Self-perception & $17.18 \pm 3.15$ & $16.83 \pm 3.14$ & $15.93 \pm 2.75$ & $15.54 \pm 2.50$ & 0.09 \\
Total Perception of Learning Environment & $136.45 \pm 16.93$ & $129.79 \pm 15.89$ & $131.13 \pm 16.37$ & $125.21 \pm 11.19$ & 0.03 \\
\hline
\end{tabular}

${ }^{\mathrm{a} O n e}$ way ANOVA

Roff [12], Said [3], Brown [15], Bakshi [18] and Bakshi [24]. However no any significant difference was found between the perception of learning environment and the other selected socio-demographic variables.

Out of total students, first year students had the highest mean score for the perception followed by third year students, second year students and the fourth year students respectively. This trend was fairly consistent among the different subscales where first year students scored more than the other years. This might be explained by the fact that first year students are not exposed to all the areas and are not too stressed by the study. The positive perception among the newcomers might have been fueled by the excitement of getting admissions in one of the reputed institution of the nation. A study conducted by Said [3] in Malaysia among the nursing students also revealed highest DREEM score among the first year students. Similar finding was seen in a study conducted by Bakshi [18] and Al-Ayed [27] among the nursing students in Iran and Suadi Arabia. However a study conducted by Roff et al. [12] in Nepalese Health profession institutions showed improved perception in the year 2 and 3 over year 1 as reflected by the DREEM scores across the years. Study conducted by Bakshi [24] in a medical college in Iran also revealed higher scores for the year second and fourth.

This study provides the valuable insight regarding the educational environment as perceived by the nursing students. The study is conducted in a single institution among limited participants. So it would be important to conduct the similar studies in other nursing institutions across the country for establishing the generalizability of the findings. Qualitative studies are recommended to have in-depth understanding of the findings, address the specific problems and highlight the strength of the particular learning environment.

\section{Conclusion}

In conclusion students in this institution revealed a positive perception of the learning environment, which varied significantly according to the year of enrollment. However improvements are required across all the five domains for the high quality educational environment.

\begin{abstract}
Abbreviations
ANOVA: One Way Analysis of Variance; BPKIHS: B. P. Koirala Institute of Health Science; DREEM: Dundee Ready Educational Environment Measure; IRC: Institutional Review Committee; SD: Standard Deviation; SPSS: Statistical Package for Social Sciences
\end{abstract}

\section{Acknowledgements}

I would like to thank Prof. Dr. Surya Raj Niraula for statistical advice and Ms. Ruby Ghimire for her support during pretesting. Similarly, I would like to extend sincere gratitude to Ms. Diksha Sapkota and Ms. Rita Pokharel for their support and encouragement during the study. I would also like to extend my humble thanks to all the participants without whom this project wouldn't have been completed.

\section{Authors' contributions}

ES developed the original idea of the study. ES and GM were involved in designing the protocol. RSM and KC provided the feedback to the protocol. ES, KC and NP collected the data. Preliminary analyses were done by ES which was then reviewed by RSM and GM. ES prepared the final draft of the manuscript. All the authors have reviewed and approved the final manuscript.

\section{Funding}

This is a non-funded research.

\section{Availability of data and materials}

The datasets generated and/or analysed during the current study are available from the corresponding author on reasonable request.

\section{Ethics approval and consent to participate}

Ethical approval was obtained from Institutional Review Committee (IRC), B.P. Koirala Institute of Health Sciences.

The IRC reference number is 391/073/074-IRC.

Written informed consent was obtained from the participant's prior to the study.

\section{Consent for publication}

Not Applicable

\section{Competing interests}

The authors declare that they have no competing interests.

\section{Author details}

'Department of Medical Surgical Nursing, B.P. Koirala Institute of Health Sciences, Dharan, Nepal. ${ }^{2}$ Department of Maternal Health Nursing, B.P. Koirala Institute of Health Sciences, Dharan, Nepal. ${ }^{3}$ Department of Psychiatric Nursing, B.P. Koirala Institute of Health Sciences, Dharan, Nepal.

Received: 12 March 2019 Accepted: 3 October 2019

Published online: 21 October 2019

\section{References}

1. Tripathy S, Dudani S. Students' perception of the learning environment in a new medical college by means of the DREEM inventory. Int J Res Med Sci. 2013;1(4):385-91.

2. Taheri M. Students' perceptions of learning environment in Guilan University of Medical Sciences. JME. 2009;13(4):127-33. 
3. Md SN, Rogayah J. Hafiazah a. a study of learning environments in the Kulliyyah (faculty) of nursing, International Islamic University Malaysia. Malays J Med Sci. 2009;16(4):15-24.

4. Sayed HY, El-Sayed NG. Students' perceptions of the educational environment of the nursing program in Faculty of Applied Medical Sciences at umm Al Qura University, KSA. J Ame Sci. 2012;8(4):69-75.

5. Bakshialiabad H, Bakhsh MH, Hassanshahi G. Students' perceptions of the academic learning environment in seven medical sciences courses based on DREEM. Adv Med Educ Pract. 2015;6:195-203.

6. Mayya S, Roff S. Students' perceptions of educational environment: a comparison of academic achievers and under-achievers at Kasturba medical college, India. Educ Health. 2004;17(3):280-91.

7. Sharkawy SA, El-Houfey AA, Hassan AK. Students' perceptions of educational environment in the faculties of nursing at Assiut, Sohag and South Valley universities. Ass Univ Bull Environ Res. 2013;16(2):167-97.

8. Miles S, Swift L, Leinster SJ, et al. Med Teach. 2012;34(9):e620-34.

9. Farajpour A, Esaashari FF, Hejazi M, Meshkat M. Survey of midwifery students' perception of the educational environment based on the DREEM model at Islamic Azad University of Mashhad in the academic year 2014 Res Dev Med Educ. 2014;4(1):41-5.

10. Denz-Penhey $\mathrm{H}$, Murdoch C. A comparison between findings from the DREEM questionnaire and that from qualitative reviews. Med Teach. 2009; 31:449-53.

11. Kohli V, Dhaliwal U. Medical students' perception of the educational environment in a medical college in India: a cross-sectional study using the Dundee Ready Education Environment questionnaire. J Educ Eval Health Prof. 2013;10(5). https://doi.org/10.3352/jeehp.2013.10.5.

12. Roff S, McAleer S, Ifere OS, Bhattacharya S. A global diagnostic tool for measuring educational environment: comparing Nigeria and Nepal. Med Teach. 2001;23(4):378-82.

13. Roff $\mathrm{S}$. The Dundee ready educational environment measure (DREEM)- a generic instrument for measuring perceptions of undergraduate health professions curricula. Med Teach. 2005;27(4):322-5.

14. Edgren G, Haffling AC, Jakobsson U, Mcaleer S, Danielsen N. Comparing the educational environment (as measured by DREEM) at two different stages of curriculum reform. Medical Teacher. 2010;32(6):e233-8. https://doi.org/10. 3109/01421591003706282.

15. Brown T, Williams B, Lyuch M. The Australian DREEM: evaluating students perceptions of academic learning environments within eight health science courses. Int J Med Educ. 2011:2:94-101.

16. Arab M, Rafiei H, Safarizadeh MH, Shojaei M, Safarizadeh MM. Nursing and Midwifery Students Perception Of Educational Environment: A Cross Sectional Study In Iran. IOSR-JNHS. 2016;5(1):64-7.

17. Imanipour M, Sadoghiasi A, Ghiyasavandian S, Haghani H. Evaluating the Educational Environment of a Nursing School by Using the DREEM Inventory. Glob J Health Sci. 2015;7(4). https://doi.org/10.5539/gjhs.v7n4p211.

18. Bakshi H, Abazari F, Bakhshialiabad M. Nursing Students' perceptions of their educational environment based on DREEM model in an Iranian University. Malays J Med Sci. 2013:20(4):56-63.

19. Victor G, Ishtiaq M, Parveen S. Nursing students' perceptions of their educational environment in the bachelor's programs of the Shifa College of nursing. Pakistan J Educ Eval Health Prof. 2016;13:43.

20. Youhasan P, Sathananthan T. Educational environment for undergraduate medicine and nursing Programme at Eastern University, Sri Lanka. Stud Percept OUSL J. 2016;11:23-35.

21. Imran N, Khalid F, Haider II, Jawaid M, Irfan M, Mahmood A, et al. Student's perceptions of educational environment across multiple undergraduate medical institutions in Pakistan using DREEM inventory. J Pak Med Assoc. 2015:6(1):24-8

22. Ugusman A, Othman NA, Razak ZNA, Soh MM, Faizul PNAK, Ibrahim SF. Assessment of learning environment among the first year Malaysian medical students. J Taibah Univ Med Sci. 2015;10(4):454-60. https://doi.org/ 10.1016/j.jtumed.2015.06.001

23. Al Sheikh MH. Educational environment measurement, how is it affected by educational strategy in a Saudi medical school? A multivariate analysis. J Taibah Univ Med Sci. 2014;9(2):115-22. https://doi.org/10.1016/j.jtumed.2013.11.005.

24. Bakshi H, Bakshialiabad MH, Hassanshahi G. Students' perceptions of the educational environment in an Iranian Medical School, as measured by The Dundee Ready Education Environment Measure. Bangladesh Med Res Counc Bull. 2014;40:36-41. https://doi.org/10.3329/bmrcb.v40i1.20335.
25. Youssef WT, Wazir YME, Ghaly MS, Khadragy R. Evaluation of the Learning Environment at the Faculty of Medicine, Suez Canal University: Students' Perceptions. Intel Prop Rights. 2013;1(102). https://doi.org/10.4172/ipr. 10001022013.

26. Enns SC, Perotta B, Paro HB, Gannam S, Peleias M, Mayer FB et al . Medical students' perception of their educational environment and quality of life: is there a positive association? Acad med. Vol. XX, No. X / XX XXXX. https:// doi.org/10.1097/ACM.0000000000000952.

27. Al-Ayed $\mathrm{IH}$, Sheik SA. Assessment of the educational environment at the College of Medicine of King Saud University, Riyadh. East Mediterr Health J. 2008;14(4):953-9.

28. Aghamolaei T, Fazel I. Medical students' perceptions of the educational environment at an Iranian Medical Sciences University. BMC Med Educ. 2010;10:87.

29. Sajid F, Rehman A, Fatima S. Perceptions of Students of the Learning Environment Studying An Integrated Medical Curriculum. J Surg Pak. 2013; 18(2):86-91.

30. Abusaad FES, Mohamed HES, El-Gilany AH. Nursing students' perceptions of the educational learning environment in pediatric and maternity courses using DREEM questionnaire. J Educ Pract. 2015;6(29):26-32.

\section{Publisher's Note}

Springer Nature remains neutral with regard to jurisdictional claims in published maps and institutional affiliations.
Ready to submit your research? Choose BMC and benefit from:

- fast, convenient online submission

- thorough peer review by experienced researchers in your field

- rapid publication on acceptance

- support for research data, including large and complex data types

- gold Open Access which fosters wider collaboration and increased citations

- maximum visibility for your research: over $100 \mathrm{M}$ website views per year

At BMC, research is always in progress.

Learn more biomedcentral.com/submissions 